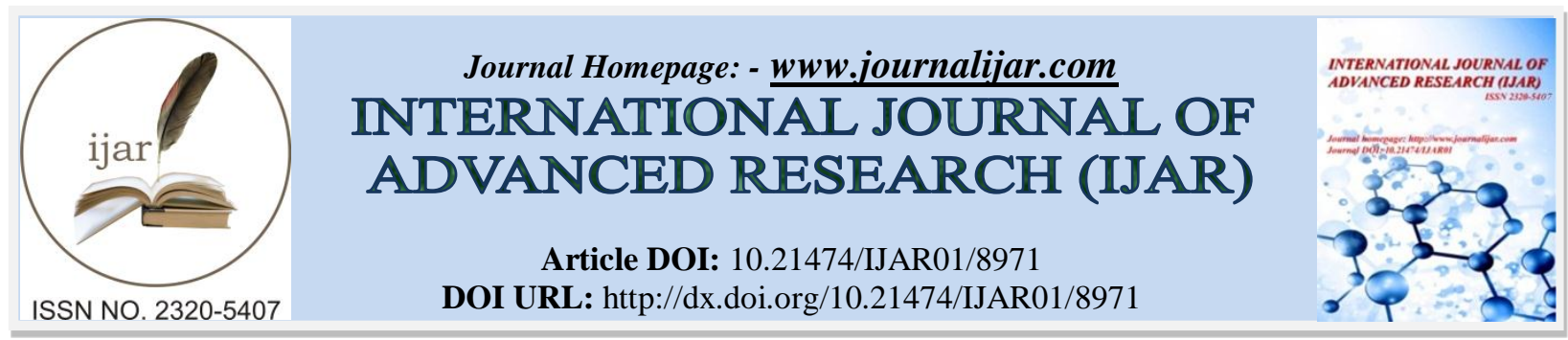

RESEARCH ARTICLE

\title{
TEACHERS AND HEADMASTERS INITIATIVES IN STRENGTHENING QUALITY EDUCATION THROUGH SCHOOL MANAGEMENT COMMITTEES.
}

\section{Bernat ${ }^{1}$ and Dr. M. Kanmani ${ }^{2}$.}

1. Ph.D- Research Scholar, Department of Education, Manonmaniam Sundaranar University, Tirunelveli.

2. Associate Professor, Department of Educational Technology, Tamil Nadu Teachers Education University, Chennai.

\section{Manuscript Info}

Manuscript History

Received: 24 February 2019

Final Accepted: 26 March 2019

Published: April 2019

\begin{abstract}
Schools are miniatures of our society. Now a day's schools are gradually isolated from the community. Our constitution and many domestic laws ensured the participation of people in governance. Right to education act has ensured School Management Committees (SMC)s in schools. SMCs are reducing the gap between communities and schools. Meantime headmasters and teachers play an important role in the SMCs. Teachers and headmasters are found stimulating and encouraging parents and community members towards strengthening the quality and universal elementary education for their children. This study tries to analyze the understanding, awareness and involvement of headmasters and teachers in the functioning of the SMCs in schools. This study tries to document good initiatives of headmasters and teachers in schools using purposive sampling method and questionnaire.
\end{abstract}

Copy Right, IJAR, 2019,. All rights reserved.

\section{Introduction:-}

The Right to Education (RTE) act ensures free and compulsory education as per the RTE act enacted in 2009. The act was a landmark milestone in primary education in India. The act ensured the universalisation of elementary education up to 14 years. The act entitled the following important provisions for children's education.

The National Policy of Education (NPE) 1986 and the Revised Plan of Action (POA) 1992 clearly envisaged decentralization as a mechanism for educational governance and a means for promoting a 'spirit of autonomy for educational institutions' in India. 73rd and 74th constitutional amendment related to 'local bodies' ensured the participation of parents, community and local bodies for better development of schools. Community participation is institutionalized with well defined structural body in every government funded schools in India. Community and schools get together for their children's quality and better education. Community participation is very essential for retaining government schools. Community participation is increasing monitoring and accountability of schools and source for local resources. In different periods different forums have emerged in schools. Like Village Education Committee (VEC), School Monitoring and Development Committee (SMDC), Parent Teachers Association (PTA), and now school management committee (SMC).

Corresponding Author:- L. Bernat. 


\section{Teacher's role in school development}

Teachers are highly influencing and respectful persons in every society. They are nation builders and promoting constitutional norms, values, tolerance and brotherhood. Teachers are the backbone for our education system. The right to education act explains about the duties of teachers and redressal of their grievances. A teacher appointed under the sub-section (1) of section 23 shall perform the following duties, namely:-

a. Maintain regularity and punctuality in attending school

b. Conduct and complete the curriculum within the specified time

c. Assess the learning ability of each child and accordingly supplement additional instructions

d. Hold regular meetings with parents and guardians and apprise them about the regularity in attendance, ability to learn, progress made in learning and any other relevant information about the child;

e. The grievances, if any, of the teacher shall be redressed in such manner as may be prescribed.

Community participation is one of the important components in RTE act. The SMCs comprises of parents, elected members of the local bodies, teachers, local educationists, and self help group members. As per government of Tamil Nadu norms of SMC (G.O.Ms.No.213) the total number of members are twenty. The composition of the SMC as described in the Act is as follows,

- Provided that three-fourth of members of such Committee shall be parents or guardians:

- Provided further that proportionate representation shall be given to the parents or guardians of children belonging to disadvantaged group and weaker section:

- Provided also that fifty percent of members of such Committee shall be women.

- The SMCs major functions are monitor the functioning of the school, Preparation, recommendation, implementation and monitoring of the School Development Plan (SDP), Monitoring of utilization of the grants.

Teachers and headmasters encourage parents and communities towards for school development. This study tries to understand the awareness and involvement of headmasters and teachers regarding the functioning of the SMCs in schools and documents the good initiatives by headmasters and teachers.

\section{Background Of The Study:-}

Sethi \& Muddgal (2017), conducted a study of role of SMC as mentioned in Right to Education Act, 2009 among Municipal Corporation Primary Schools of Delhi. It can be revealed from the findings that understand the socioeconomic complexities that influence the functioning of the organization. The SMC members are not aware of the RTE Act and its components related to SMC. It is the awareness that leads to the participation and empowerment of the members. School Development Plan (SDP), is an important component of SMC. No school has formulated SDP. SMC members are not even aware of the SDP and no discussion has been done in the meetings.

Owusu \& Sam (2012), conducted a study on Assessing the Role of School Management Committees (SMCs) In. Improving Quality Teaching and Learning in Ashanti Mampong Municipal Basic Schools. The study findings revealed that the monitoring and supervision of head teachers and teacher's and pupil's attendance by SMC's members was ineffective. Even though SMC's are not doing enough to assist teachers to improve teaching and learning, they are seen as very effective in solving school community relations since SMCs are relatively on task on the issue of serving as a vehicle for promoting community participation in the provision of quality education. This calls for serious consideration of strategies to be adopted in order to achieved the improvement of quality teaching and learning at the basic schools in Mampong Municipal.

Community participation is one of the important components in RTE act. The SMCs comprises parents, elected members of the local bodies, teachers, local educationists, and self help group members. As per government of Tamil Nadu norms of SMC (G.O.Ms.No.213) the total number of members are twenty. The composition of the SMC as described in the Act is as follows,

- Provided that three-fourth of members of such Committee shall be parents or guardians:

- Provided further that proportionate representation shall be given to the parents or guardians of children belonging to disadvantaged group and weaker section:

- Provided also that fifty percent of members of such Committee shall be women.

- The SMCs major functions are monitor the functioning of the school, Preparation, recommendation, implementation and monitoring of the School Development Plan (SDP), Monitoring of utilization of the grants. 
Teachers and headmasters encourage parents and communities towards for school development. This study tries to understand the awareness and involvement of headmasters and teachers regarding the functioning of the SMCs in schools and documents the good initiatives by headmasters and teachers.

\section{Rearch Method}

The study is both quantitative and qualitative in nature. This study elucidates the understanding, awareness and involvement of headmasters and teachers in the functioning of the SMCs in schools. It describes a process taking place in relation to the schools, teachers, headmasters and communities.

\section{Sampling Technique}

Purposive sampling technique is used by the investigator for collecting the data from 40 teachers and headmasters.

\section{Research Tool And Analysis}

Data was collected using self-administered questionnaire by the investigator. The questionnaire is a quantitative data collection instrument by local language. Quantitative data was analyzed and the demographic variables are described. The variables are described using simple frequency tables.

\section{Analysis And Findings}

The main purpose of the study was to assess the awareness of the teachers and headmasters related to SMC in schools under RTE and also assess the functioning and involvement of teachers and headmasters. The collected data was analyzed using percentage analysis and the results have been discussed.

\section{Awareness of Teachers and Headmasters related to RTE and SMC in School}

The data pertaining to the awareness of the teachers and headmasters on right to education and role and functions of school management committee have been presented in table-1.

Table-1 Teachers and HM's awareness level related to SMCs

\begin{tabular}{|l|l|l|l|}
\hline S.No & Level of awareness of RTE \& SMCs & Responded & \\
\hline & & Frequency & Percentage \\
\hline 1 & Low & 8 & 20 \\
\hline 2 & Moderate & 32 & 80 \\
\hline
\end{tabular}

Table-1 reveals that $20 \%$ of SMC members are with low level of awareness and the rest of $80 \%$ of SMC members are of moderate level of awareness related to RTE and SMC.

\section{Functioning of SMCs in School}

The data pertaining to the functioning of school management committees have been presented in table- 2 .

Table-2 Functioning of SMCs in Schools

\begin{tabular}{|l|l|l|l|}
\hline S.No & Functioning level of SMCs in Schools & Responded \\
\hline & & Frequency & Percentage \\
\hline 1 & Low & 7 & 17.5 \\
\hline & Moderate & 31 & 77.5 \\
\hline 2 & High & 2 & 5.0 \\
\hline
\end{tabular}

It is inferred from the table- 2 that $17.5 \%$ of Teachers and HMs stated that functioning of SMCs in schools are low level and $5 \%$ of the respondents stated that high level of functioning and rest of $77.5 \%$ of the respondents stated that moderate level of functioning in schools.

Selection of SMC members

The data pertaining to the selection of SMC members in Schools

Table-3 Selection of SMC members

\begin{tabular}{|l|l|l|l|}
\hline S.No & Variables & Responded \\
\hline & & Frequency & Percentage \\
\hline 1 & Parents meetings & 8 & 20 \\
\hline 2 & Nominated by HMs & 12 & 30 \\
\hline
\end{tabular}




\begin{tabular}{|l|l|l|l|}
\hline 3 & Executive members & 13 & 32.5 \\
\hline 4 & Didn't know their roles and responsibilities & 7 & 17.5 \\
\hline
\end{tabular}

It is inferred from the table- 3 that $20 \%$ of the respondents are selected through parents meeting $30 \%$ of members are nominated by head of the school and $32.5 \%$ of the responders are executive members and $17.5 \%$ of the respondents stated that they did not know their roles and responsibilities.

\section{Training to SMC members}

The data pertaining to know if training was provided to the SMC members are as follows,

Table-4 Training on SMC

\begin{tabular}{|l|l|l|l|}
\hline S.No & Variables & Responded & \\
\hline & & Frequency & Percentage \\
\hline 1 & Schools & 6 & 15 \\
\hline 2 & CRC & 26 & 65 \\
\hline 3 & BRC & 8 & 20 \\
\hline
\end{tabular}

It is inferred from the table -4 , that $15 \%$ of the respondents have stated that they are getting training in schools and $65 \%$ of members are getting training in cluster resource centers and rest of the $20 \%$ members are getting training in block resource centers.

\section{Reason for non-participation in SMC trainings}

The data pertaining to the reason for non-participation in SMC trainings

Table-5 Reason for non-participation in SMC trainings

\begin{tabular}{|l|l|l|l|}
\hline S.No & Variables & Responded \\
\hline & & Frequency & Percentage \\
\hline 1 & No proper information & 4 & 10 \\
\hline 2 & Due to existing works & 22 & 55 \\
\hline 3 & domestic and Agricultural works & 3 & 7.5 \\
\hline 4 & Some other reasons & 11 & 27.5 \\
\hline
\end{tabular}

Table-5 above data shows that the $10 \%$ of the SMC members stated that no proper information had been provided for members and 55\% of the respondents stated that due to existing workload they were not able to participate, $7.5 \%$ of the respondents stated that due to domestic and agricultural works they were not able to participate and $27.5 \%$ of the respondents stated that due to some other reason they were not able to participate in the SMC trainings.

Frequency of SMC meetings

The data pertaining to the frequency of SMC meetings

Table-6 Frequency of SMC meetings

\begin{tabular}{|l|l|l|l|}
\hline S.No & Variables & Responded & \\
\hline & & Frequency & Percentage \\
\hline 1 & Once a month & 29 & 72.5 \\
\hline 2 & One in two months & 5 & 12.5 \\
\hline 3 & once in three to five months & 6 & 15.0 \\
\hline
\end{tabular}

Table- 6 above data shows that the $72.5 \%$ of the schools had conducted SMC meetings once a month and $12.5 \%$ of the respondents stated that once in two months they had conducted the SMC meetings and $15 \%$ of the respondents stated that the meetings were conducted once in three to five months.

\section{Number of members participating in the SMC meetings}

The data pertaining to the number of members participating in SMC meetings

Table-7 Number of members participating in SMC meetings

\begin{tabular}{|l|l|l|l|}
\hline S.No & Variables & Responded & \\
\hline & & Frequency & Percentage \\
\hline 1 & 16 to 20 & 14 & 35.0 \\
\hline
\end{tabular}




\begin{tabular}{|l|l|l|l|}
\hline 2 & 11 to 15 & 7 & 17.5 \\
\hline 3 & 5 to 10 & 12 & 30.0 \\
\hline 4 & Less than 5 & 13 & 17.5 \\
\hline
\end{tabular}

Table-7 above data shows that the $35 \%$ of the respondents stated that average number of members ranging from 16 to 20 participated in SMC meetings and $17.5 \%$ of the stated that 11 to 15 members had participated in SMC meetings and $30 \%$ of the respondents stated that 5 to 10 members participated and $17.5 \%$ of the respondents stated that less than 5 members participated in SMC meetings.

\section{Reasons for Non participation in SMC meetings}

The data pertaining to the reasons for non participation in SMC meetings

Table-8 Reasons for non participation in SMC meetings

\begin{tabular}{|l|l|l|l|}
\hline S.No & Variables & Responded \\
\hline & & Frequency & Percentage \\
\hline 1 & Some other works & 11 & 27.5 \\
\hline 2 & lack of proper information and Lack of interest & 7 & 17.5 \\
\hline 3 & Not conducted properly & 18 & 45.0 \\
\hline 4 & some other reasons & 4 & 10.0 \\
\hline
\end{tabular}

Table- 8 above data shows that the $27.5 \%$ of the respondents stated that non participation in SMC meetings was due to some other works and $17.5 \%$ of the stated that the timings of the meetings were not suitable and lack of proper information or lack of interest. $45 \%$ of the respondent stated that not conducted meetings properly and $10 \%$ of the respondent stated that it was due to family and some other reasons.

Mode of communication for SMC meetings

The data pertaining to the mode of communication regards SMC meetings

Table-9 Mode of communication

\begin{tabular}{|l|l|l|l|}
\hline S.No & Variables & Responded & \multicolumn{2}{l|}{} \\
\hline & & Frequency & Percentage \\
\hline 1 & Direct communication & 7 & 17.5 \\
\hline 2 & Through students & 16 & 40.0 \\
\hline 3 & Through phone & 16 & 40.0 \\
\hline
\end{tabular}

Table- 9 above data shows that the $17.5 \%$ of the respondents stated that they had directly communicated with the members and $40 \%$ stated that they communicated through students and $40 \%$ of the respondent stated that they communicated through phone.

\section{Case Study -1}

Arasaveli government middle school in Tiruvannamalai district, state that the teachers and headmasters took lot of school development programs with support of community. School buildings, morning breakfast for children and appointment of additional teachers, teachers organization of various skill development programs for their children were done here Children had also participated in district and state level competitions. Teachers are found to concentrate on the school hygiene and children health issues.

\section{Case Study-2}

Melarathanallur government middle school in Tiruvarur district, teachers had taken various initiatives for teaching, learning and school development. They had conducted parents meeting and submitted the school progress report in parent meeting. Continues touch with SMC members as well as community members. Reading camps, children expression box, village exposure programs with community members, safety and first aid, simple science experiments and some other appropriate programs are taken by teachers.

\section{Educational Implications}

Based on the findings of the study the following suggestions and recommendations are given as follows,

- Schools and education authority should ensure parents and teachers participation in SMC meetings.

- Conduct RTE awareness program for parents and community

- Conducting needs assessment and remedial programs.

- Develop mutual understanding between teachers and community members. 
- Encourage school development plan prepare by SMC members

- Evolve the strategies for Non-participation and cooperation from community.

- Ensure the credibility and accountability to public

- Educational authorities should ensure the conduct of SMC meetings every month

- Printing of pamphlet, Poster and booklet about role and functions of SMC members.

- SMC members to ensure quality of education for their children through monitoring of teaching learning process.

\section{Conclusion:-}

School management committee (SMC) is important towards community engaged system in schools. SMCs are a bridge between schools and community. Government funded schools are not only accountable to appropriate government it's also accountable to community. We will practice democratic participation from bottom to top. Awareness on SMCs is very essential. Government and education authorities put more concentration to community based awareness on Right to Education.

\section{References:-}

1. Das, D. K. (2015). SMC Participation: A Step Towards Development Of Primary Education In A Tribal District Gajapati Of Odisha. International Journal of Informative \& Futuristic Research , Volume 2 (Issue 9), 33343349.

2. Jha, J., Ghatak, N., Minni, P., \& Prasad, G. (2005) A Study on the impact of training on SMC members and functioning of the SMC: Evidence from Jharkhand, Final Report. Centre for Budget and Policy Studies.

3. Owusu, O. B., \& Sam, K. F. (2012). Assessing the Role of School Management Committees (SMCs) In. Journal of Emerging Trends in Educational Research and Policy Studies , 3(5), 611-615.

4. Sethi, C., \& Muddgal, A. (2017). A study of role of SMC as mentioned in Right to Education Act, 2009 among Municipal Corporation Primary Schools of Delhi. Learning Community, 8(1), 39-47. 